\title{
Analisis Hubungan Faktor Lingkungan Fisik Terhadap Keberadaan Jumlah Nyamuk Aedes Aegypti di Kota Bandung
}

\author{
Analysis of The Relation of The Physical Environment Factor to The Density of Aedes \\ Aegypti Mosquitoes in Bandung City
}

Obin Sarwita $^{1,2}$, Bachti Alisjahbana ${ }^{2}$, Dwi Agustian ${ }^{2}$

Inspektorat Kabupaten Bekasi ${ }^{1},{ }^{2}$ Program Studi Magister Epidemiologi Fakultas Kedokteran

Universitas Padjajaran Bandung

Korespodensi Penulis:

Obin Sarwita

Email: binbin.sarwita@gmail.com

\begin{abstract}
Abstrak
Latar belakang : Penyakit dengue sampai saat ini belum dapat dikendalikan dengan baik. Transmisi virus dengue ke manusia disebabkan oleh interaksi yang kompleks dan dinamis oleh beberapa faktor diantaranya lingkungan fisik, biologi dan sosial. Penelitian ini bertujuan untuk mengetahui hubungan lingkungan fisik dengan keberadaan nyamuk Aedes aegypti penyebab penyakit dengue di Kota Bandung. Metode : Penelitian ini merupakan studi ekologi dangan pendekatan cross sectional. Populasi dalam penelitian ini adalah seluruh bangunan rumah di Kota Bandung. Besar sampel sebanyak 160 rumah yang terpilih dengan multistage random sampling. Data keberadaan jumlah nyamuk diperoleh dari alat perangkap nyamuk yang dipasang di 16 kelurahan. Analisis bivariat menggunakan korelasi rank spearman, uji man whitney dan kruskal walis. Analisis multivariate menggunakan regresi zero inflated poisson. Hasil : Luas ventilasi, kepadatan hunian, jumlah baju menggantung, kelembaban udara dan suhu udara tidak berkorelasi dengan jumlah nyamuk Aedes aegypti, sedangkan penampungan air positif jentik positif jentik memiliki korelasi positif dan signifikan terhadap jumlah nyamuk Aedes aegypti $(\mathrm{p}=0.017)$. Hasil analisis menggunakan regresi Zero Inflated Poisson, ,tidak ada variabel yang signifikan dengan nilai $p>0,05$ dan nilai $A I C=360$. Kesimpulan: Ada korelasi positif dan signifikan antara tempat penampungan air positif jentik dengan jumlah nyamuk Aedes aegypti. Analisis dengan model zero inflated poisson tepat digunakan pada penelitian ekologi dimana observasi dengan nilai nol lebih banyak ditemukan.
\end{abstract}

Kata kunci: Aedes Agypti, keberadaan nyamuk, lingkungan fisik

\begin{abstract}
Background:Up until the present, dengue disease has not been successfully controlled. Transmission of dengue virus to humans is caused by complex and dynamic interactions due toa number of factors including the physical, biological, and social environments. This research aims to determine the relation of the physical environment to the density of Aedes aegypti mosquitos causing dengue disease in the city of Bandung. Methods:This research is an ecological study with a cross-sectional approach. The population in this research was all households in the city of Bandung. The sample consisted of 160 households collected using the multistage random sampling technique. The data on the density of mosquitoes were obtained from the mosquito traps installed in 16 kelurahan (urban villages). The bivariate analysis used the spearman rank correlation, and the mann-whitney and kruskal walis test. The multivariate analysis used the zero-inflated poisson regression. Results:The size of ventilation, occupancy density, number of pieces of clothes hung, humidity and air temperature do not correlate with the density of Aedes aegypti mosquitoes, where as larvaepositive containers with standing water have a positive and significant correlation to the density of Aedes aegypti mosquitoes $(p=0.017)$. The results of the analysis using the zero-inflated poisson regression show that there are no significant variables with a $p$ value of $>0.05$ and an AIC value of 360 . Conclusion:There is a positive and significant correlation between larvae-positive containers with standing water and the density of Aedes aegypti mosquitoes. The use of analysis using the zero-inflated Poisson model is appropriate in an ecological research where observations with a zero value are found more frequently.
\end{abstract}

Keywords:Aedes aegypti, mosquito density, physical environment

The Indonesian Journal of Infectious Diseases | Volume 4 No. 1 


\section{Pendahuluan}

Berdasarkan data $\mathrm{WHO}$, kasus penyakit dengue banyak tidak dilaporkan dan terjadi kesalahan klasifikasi pada kasus ini, sehingga upaya pencegahan dan pengendalian belum dapat dilakukan secara maksimal. Penelitian terbaru menunjukkan 390 juta infeksi dengue per tahun dan 96 juta diantaranya bermanifestasi klinis dengan berbagai derajat. $^{(1)}$ Penelitian lain menyatakan, angka kejadian penyakit dengue diperkirakan mencapai 3,9 milyar orang di 128 negara berisiko terinfeksi virus dengue. $^{(2)}$

Epidemi dengue merupakan masalah kesehatan yang sangat besar bagi negara beriklim tropis, salah satunya Indonesia. Pada tahun 2015 jumlah penderita DBD yang dilaporkan sebanyak 129.650 kasus dengan jumlah kematian sebanyak 1.071 orang (IR/Angka kesakitan $=50,75$ per 100.000 penduduk dan CFR/angka kematian= 0,83\%). Dibandingkan tahun 2014 dengan kasus sebanyak 100.347 serta IR 39,80 terjadi peningkatankasus pada tahun 2015. Target Renstra Kementerian Kesehatan untuk angka kesakitan DBD tahun 2015 sebesar < 49 per 100.000 penduduk, dengan demikian Indonesia belum mencapai target Renstra 2015. (3)
Berdasarkan model segi tiga epidemiologi (triangle epidemiology), ada tiga faktor yang berperan dalam timbulnya suatu penyakit yaitu pejamu, agen penyakit dan lingkungan (host, agent and environment). Faktor lingkungan berupa lingkungan fisik, biologi dan sosial. Faktor nyamuk yang memengaruhi penyebaran penyakit dengue adalah jenis nyamuk yang dominan menjadi vektor yaitu Aedes aegypti betina dan siklus hidupnya mulai dari telur, larva/jentik hingga nyamuk dewasa. Faktor virus yang memengaruhi penyebaran penyakit dengue yaitu virus dengue mempunyai empat serotipe DENV 1, DENV 2, DENV 3, dan DENV 4. ${ }^{(4,5)}$

Penyakit dengue sampai saat ini belum sepenuhnya dapat dikendalikan. Angka kesakitan selalu berfluktuatif disertai Kejadian Luar Biasa (KLB) secara sporadik. Beberapa penelitian menunjukkan bahwa angka kejadian penyakit dengue sangat dipengaruhi oleh faktor lingkungan. Beberapa menyatakan bahwa ada hubungan yang signifikan antara faktor lingkungan fisik, seperti suhu udara, kelembaban dan curah hujan dan tempat penampungan air dengan kejadian penyakit dengue, selain itu faktor lingkungan juga berhubungan dengan keberadaan jentik nyamuk Aedes 
aegypti. $^{(6,7)}$ Pada penelitian yang dilakukan Arifin dkk di Makasar menyebutkan bahwa suhu udara, suhu air dan kelembaban mempunyai hubungan bermakna dengan keberadaan larva Aedes aegypti. ${ }^{(8)}$

Keberadaan larva Aedes aegypti disuatu daerah dapat menjadi peringatan terhadap penyebaran penyakit penyakit dengue. Beberapa faktor lingkungan fisik lain yang memengaruhi distribusi Aedes sp. adalah ketinggian, suhu udara dan lokasi yang terdapat banyak genangan air. Suhu udara merupakan salah satu faktor lingkungan yang memengaruhi perkembangan jentik nyamuk Aedes aegypti. Rata-rata suhu optimum untuk pertumbuhan nyamuk adalah $25-27^{\circ} \mathrm{C}$ danpertumbuhan nyamuk akan berhenti sama sekali bila suhu kurang dari $10^{\circ} \mathrm{C}$ atau lebih dari $40^{\circ} \mathrm{C}$. ${ }^{(9)}$ Pada penelitian Rustam Aji didapatkan bahwa larva Aedes aegypti paling banyak terdapat di kolam (87,10\%), disusul oleh drum $(16,13 \%)$ dan Bretau indeks (BI) paling banyak pada kolam $(62,16 \%)$. Konstruksi atap rumah/bangunan memiliki potensi menjadi tempat perindukan nyamuk Aedes aegypti.(10) Atap yang datar menyebabkan aliran air lebih lambat sehingga berpotensi menjadi tempat perindukan nyamuk. ${ }^{(5,11)}$
Berdasarkan fakta-fakta tersebut maka perlu dilakukan penelitian mengenai hubungan antara faktor lingkungan fisik dengan keberadaan nyamuk Aedes aegypt. Penelitian ini perlu dilakukan karena penelitian mengenai hubungan lingkungan fisik dengan kejadian penyakit dengue atau keberadaan jentik nyamuk Aedes aegypti sudah banyak dilakukan, akan tetapi penelitian mengenai hubungan faktor lingkungan fisik dengan keberadaan nyamuk masih sangat terbatas. Jadi penelitian ini akan memberikan informasi faktor lingkungan apa saja yang berhubungan dengan keberadaan nyamuk Aedes aegypti. Penelitian akan dilakukan di Bandung.

Pemilihan lokasi penelitian di Kota Bandung didasarkan pada jumlah penduduk yang relatif padat dan merupakan daerah urban yang rentan terhadap kejadian dengue. Berdasarkan data profil dinas kesehatan Provinsi Jawa Barat tahun 2014, jumlah penduduk provinsi Jawa Barat adalah 46.300.434 jiwa, dengan kepadatan penduduk 1.225.39 jiwa per $\mathrm{km}^{2}$. Jumlah kasus penyakit dengue yang dilaporkan tercatat sebanyak 19.139 orang. Data kasus dengue menunjukan peningkatan mulai dari tahun 2008 sebesar 3995 kasus sampai dengan tahun 2013 sebesar 
5736 kasus. Meskipun terjadi penurunan kasus di tahun 2014 menjadi 3144 kasus akan tetapi angka kejadian kasus tersebut masih tetap tinggi di Kota Bandung. ${ }^{(12,13)}$

\section{Metode}

Penelitian ini merupakan studi ekologi dangan pendekatan cross sectional. Populasi pada penelitian ini adalah seluruh bangunan rumah di Kota Bandung. Adapun sampel pada penelitian ini adalah bangunan/rumah di Kota Bandung yang terpilih dengan multistage random sampling. Besar sampel dalam penelitian ini 160 rumah. Pengumpulan data primer menggunakan : mosquito trap untuk menghitung jumlah nyamuk Aedes aegypti, termometer dan hygrometer untuk mengukur suhu dan kelembaban, roll meter untuk mengkur luaas ventilasi dan luas rumah. Pemeriksaan jentik dilakukan oleh peneliti terhadap TPA dengan bantuan senter. Hasil pemeriksaan dicatat dalam formulir observasi. Analisa data secara univariat berupa distribusi frekuensi dan central tendency berupa mean/median, Analisis bivariat menggunakan korelasi rank spearman, uji man whitney dan kruskal walis sedangkan analisis multivariate menggunakan regresi Zero Inflated Poisson (ZIP).

\section{Hasil}

Pada penelitian ini terpilih sejumlah 160 rumah dari 16 kelurahan. Masingmasing kelurahan dipilih satu RW dan dari setiap RW dipilih secara random sampling sesuai dengan skema sampling. Distribusi jumlah nyamuk disetiap kelurahan pada tabel 1, terlihat perolehan jumlah nyamuk di setiap kelurahan dan tiap rumah yang bervariasi dengan jumlah perolehan terbanyak 15 nyamuk Aedes aegypti dari 10 rumah, sementara itu di 2 Kelurahan tidak ditemukan nyamuk sama sekali.

\begin{tabular}{|c|c|c|c|}
\hline No & Kelurahan & $\begin{array}{c}\text { Total } \\
\text { Jumlah } \\
\text { Nyamuk }\end{array}$ & $\begin{array}{c}\text { Min- } \\
\text { Max/ } \\
\text { rumah }\end{array}$ \\
\hline 1 & Sukabungah & 15 & $0-5$ \\
\hline 2 & Pasteur & 13 & $0-7$ \\
\hline 3 & Ciateul & 11 & $0-3$ \\
\hline 4 & Nyengseret & 10 & $0-2$ \\
\hline 5 & $\begin{array}{l}\text { Sukapada } \\
\text { Antapani }\end{array}$ & 10 & $0-4$ \\
\hline 6 & Wetan & 9 & $0-3$ \\
\hline 7 & Lebak Siliwangi & 9 & $0-2$ \\
\hline 8 & $\begin{array}{l}\text { Sukamaju } \\
\text { Cibaduyut }\end{array}$ & 8 & $0-4$ \\
\hline 9 & Wetan & 7 & $0-3$ \\
\hline 10 & Cipedes & 7 & $0-7$ \\
\hline 11 & Tamansari & 7 & $0-3$ \\
\hline 12 & Cigadung & 4 & $0-1$ \\
\hline 13 & Cigondewah & 2 & $0-2$ \\
\hline 14 & Cikutra & 1 & $0-1$ \\
\hline 15 & Cijawura & 0 & $0-0$ \\
\hline 16 & Sukaasih & 0 & $0-0$ \\
\hline
\end{tabular}

Jumlah nyamuk yang ditemukan disetiap rumah yang terpilih jumlahnya 
berbeda beda, tampak dari 160 rumah yang diteliti, 104 rumah (65\%) tidak ditemukan nyamuk, sedangkan dari rumah yang ditemukan nyamuk bervariasi dari satu sampai dengan tujuh (35\%) (Gambar 1). Proporsi data yang bernilai nol diatas 63,7 \% (Gambar 1), dengan demikian untuk menganalisis hubungan antara variabel terikat lebih tepat digunakan model regresi Zero Inflated Poisson (ZIP). ${ }^{(14)}$
Nilai statistik deskriptif univariabel tersaji dalam Tabel. 2. Hasil uji normalitas data diperoleh nilai $\mathrm{p}<0,05$ artinya data tidak berdistribusi normal, sehingga pada tahap selanjutnya untuk menganalisis hubungan antara setiap variabel independen dan terikat digunakan analisis non parametrik dan pemodelan dipilih pemodelan regresi Zero Inflated Poisson.

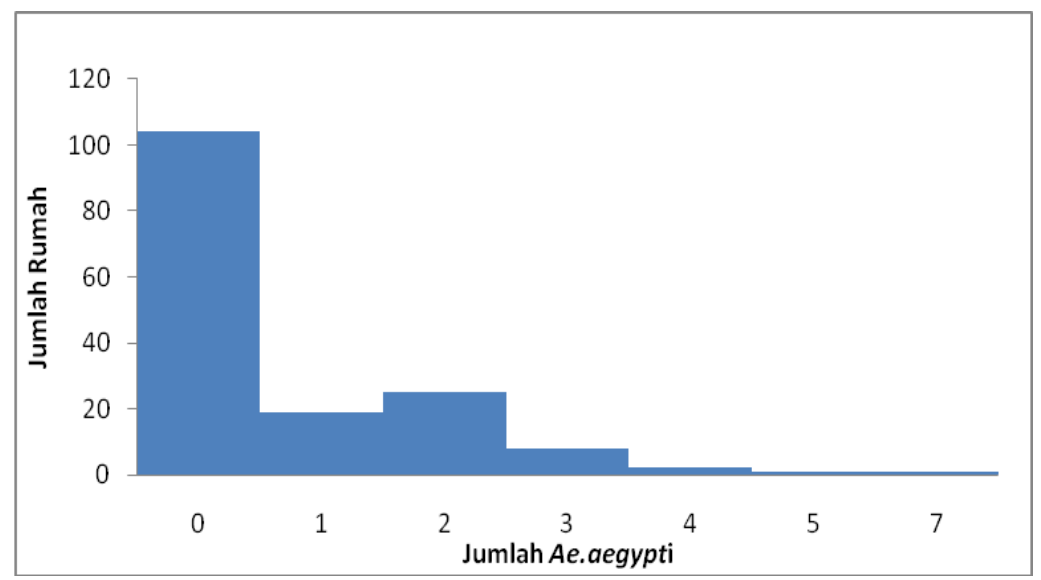

Gambar 1. Distribusi Jumlah Nyamuk Aedes aegypti di 16 Kelurahan di Kota Bandung ( $n=160$ rumah)

Tabel 2. Statistik Deskriptif dan Uji Normalitas

\begin{tabular}{|c|c|c|}
\hline Variabel & $\mathrm{n}=160$ & Uji normalitas data $\left(\right.$ nilai $\left.P^{\star}\right)$ \\
\hline Jumlah nyamuk Aedes aegypti (Median,(Min-Max) & $0(0-7)$ & $<0,001$ \\
\hline Luas ventilasi $\mathrm{m}^{2}$,median (min-max) & $0.5(0-7830)$ & $<0,001$ \\
\hline Kepadatan Hunian ( $\sum$ orang $\left./ \mathrm{m}^{2}\right)$, median (min-max) & $0.07(0-1.7)$ & $<0,001$ \\
\hline TPA positif jentik (median (min-max) & $1(0-5)$ & $<0,001$ \\
\hline Jumlah baju menggantung (median (min-max) & $6(0-60)$ & $<0.001$ \\
\hline Kelembaban udara (\%) median (min-max) & $55,75(30,1-81)$ & $<0,002$ \\
\hline Suhu udara $\left({ }^{\circ} \mathrm{C}\right)$, median (min-max) & $30,85(25-65,3)$ & $<0,002$ \\
\hline \multicolumn{3}{|l|}{ Keberadaan talang air } \\
\hline Ya (n,\%) & $94(58,8)$ & \\
\hline Tidak (n, \%) & $66(41,2)$ & \\
\hline \multicolumn{3}{|l|}{ Tipe Atap } \\
\hline Miring $(n, \%)$ & $109(68,1)$ & \\
\hline Datar $(n, \%)$ & $23(14,4)$ & \\
\hline Miring dan datar $(\mathrm{n}, \%)$ & $28(17,5)$ & \\
\hline
\end{tabular}


Tabel 3. Hubungan antara Variabel Lingkungan, Keberadaan Talang Rumah dan Tipe Atap Rumah dengan Keberadaan Nyamuk Aedes Aegypti

\begin{tabular}{|c|c|c|}
\hline Variabel & Korelasi & Nilai $P$ \\
\hline Luas ventilasi & $-0,094$ & 0,239 \\
\hline $\begin{array}{l}\text { Kepadatan } \\
\text { hunian }\end{array}$ & $-0,083$ & 0,298 \\
\hline TPA positif jentik & 0,188 & 0,017 \\
\hline $\begin{array}{l}\text { Jumlah baju } \\
\text { menggantung }\end{array}$ & 0,028 & 0,725 \\
\hline $\begin{array}{l}\text { Kelembaban } \\
\text { udara }\end{array}$ & 0,087 & 0,275 \\
\hline $\begin{array}{l}\text { Suhu udara } \\
\text { Keberadaan } \\
\text { talang rumah }\end{array}$ & $-0,092$ & $\begin{array}{l}0,244 \\
\left.0,948^{*}\right)\end{array}$ \\
\hline Tipe atap rumah & & $0,275^{* *}$ \\
\hline
\end{tabular}

Hasil analisis korelasi rank Spearman, variabel luas ventilasi, kepadatan hunian, jumlah baju menggantung, kelembaban udara dan suhu udara tidak berkorelasi dengan jumlah nyamuk Aedes aegypti, sedangkan antara TPA positif jentik memiliki korelasi positif yang signifikan terhadap jumlah nyamuk Aedes aegypti di Kota Bandung. Analisis antara keberadaan talang rumah dan tipe atap rumah dengan keberadaan nyamuk Aedes aegypti tidak bermakna ( $p>0.05)$ (Tabel 3).

Tabel 4. Hasil Analisis Multivariabel Hubungan Berbagai Variabel Lingkungan dengan Jumlah Nyamuk Aedes Aegypti

\begin{tabular}{lccc}
\hline \multirow{2}{*}{ Variabel } & \multicolumn{3}{c}{ ZIP Model } \\
\cline { 2 - 4 } & $\beta$ & Nilai P & AIC \\
\hline TPA Positif Jentik & 0,08 & 0,40 & 360 \\
Kelembaban Udara & 0,01 & 0,37 & \\
Suhu Udara & $-0,06$ & 0,22 & \\
Tipe Atap Rumah & 0,18 & 0,37 & \\
\hline
\end{tabular}

Hasil analisis multivariabel menggunakan regresi ZIP, keempat variabel tersebut tidak memiliki hubungan yang signifikan dengan jumlah nyamuk Aedes aegypti (nilai $\mathrm{p}>0,05$ ) dan nilai $\mathrm{AIC}=360$.

\section{Pembahasan}

Variabilitas jumlah nyamuk cukup besar.Hal ini terlihat di kelurahan Pasteur dan Cipedes dengan nilai minimum dan maksimum jumlah nyamuk Aedes aegypti berkisar antara 0-7 nyamuk. Hal ini sangat berbeda dengan kelurahan lain yang rata - rata jumlah nyamuknya berkisar 2-5 nyamuk. Sementara itu terdapat 2 kelurahan dimana tidak ditemukannya nyamuk sama sekali. Menurut Backer dan Storch di Jerman, bervariasinya keberadaan nyamuk tersebut dipengaruhi oleh siklus pertumbuhan dan perkembangan larva dan pupa nyamuk Aedes aegypti yang bersifat dinamis dan sensitive terhadap perubahancuaca khususnya curah hujan.Secara umumsiklus pertumbuhan nyamuk sangat dipengaruhi oleh interaksi dinamis antarafaktor abiotik dan biotik. Menurut Barrera et al. faktor abiotik seperti curah hujan, temperatur, dan evaporasi dapat mempengaruhi kegagalan telur,larva dan pupa untuk menjadi nyamuk dewasa. ${ }^{(15,16)}$ 
Menurut Jacob, dkk nyamuk Aedes membutuhkan rata-rata curah hujan lebih dari $500 \mathrm{~mm}$ pertahun untuk proses metabolisme. (17) Penelitian Azhari menyatakan bahwa pada curah hujan $140 \mathrm{~mm}$ dapat menghambat perkembangbiakan larva. ${ }^{(18)}$

Gambar 1, tampak bahwa nyamuk Aedes aegypti tidak banyak ditemukan. Hal ini mungkin disebabkan oleh salah satunya faktor cuaca. Penelitian ini dilakukan pada bulan April s.d Juni 2017 dimana cuaca di Kota Bandung dalam kondisi curah hujan yang rendah. Berkurangnya curah hujan mengakibatkan air pada kontainer atau wadah di penampungan-penampungan yang ada di rumah-rumah menjadi kering. Kondisi ini menurunkan tingkat reproduksi nyamuk Aedes aegypti.

Perkembangan dari telur hingga nyamuk dewasa membutuhkan waktu 7 8 hari dan akan lebih lama jika kondisi lingkungan tidak mendukung seperti musim kemarau. ${ }^{(19)}$ Idealnya pengukuran keberadaan nyamuk Aedes aegypti untuk melihat wadah yang positif jentik dilakukan dengan memperhitungkan siklus larva tersebut menjadi nyamuk dewasa, dengan pemasangan alat mosquito trap di rumah dan pengukuran berulang (repeated measures) yang lebih panjang waktunya (longitudinal).
Keberadaan jentik Aedes aegypti di suatu daerah merupakan indikator terdapatnya populasi nyamuk Aedes aegypti di daerah tersebut. ${ }^{(20)}$ Penanggulangan vektor nyamuk Aedes aegypti mengalami masalah yang cukup kompleks, Tetapi cara paling baik untuk mencegah penyakit ini adalah dengan pemberantasan jentik nyamuk Aedes aegypti. Memutus siklus hidup nyamuk adalah dengan cara yang tepat dalam mengurangi vektor penyakit dengue. ${ }^{(21)}$

Hasil analisis diketahui bahwa variabel terikat seperti variabel luas ventilasi, kepadatan hunian, jumlah baju menggantung, kelembaban udara dan suhu udara tidak memiliki korelasi yang signifikan dengan jumlah nyamuk Aedes aegypti di Kota Bandung, sedangkan tempat penampungan air positif jentik memiliki korelasi positif yang signifikan terhadap jumlah nyamuk Aedes aegypti di Kota Bandung sebesar $r=0,188$ dan $p=0,017$ yang berarti semakin banyak tempat penampungan air yang berjentik maka jumlah nyamuk Aedes aegypti semakin banyak, karena jentik nyamuk merupakan cikal bakal nyamuk dewasa yang dapat diamati di sarangsarang nyamuk. Semakin banyak jentik nyamuk yang ditemukan, semakin banyak nyamuk dewasa yang akan beterbangan. 
Pada analisis multivariabel, tempat penampungan air positif jentik memiliki nilai $p>0,05$ yang berarti tidak ada hubungan antara TPA positif jentik dengan keberadaan jumlah nyamuk Aedes aegypti di Kota Bandung. Tidak adanya hubungan antara TPA positif jentik dikarenakan adanya perubahan cuaca yang telah memasuki musim kemarau. Musim kemarau menyebabkan lingkungan menjadi kering sehingga wadah/kontainer yang peneliti observasi banyak yang tidak memiliki air/kering dan TPA baik yang ada di luar rumah ataupun di dalam rumah menjadi sangat sedikit. Penelitian ini sesuai dengan penelitian yang dilakukan oleh Kanchana Nakhapakorn di Sukhotai Thailand bahwa faktor cuaca mempengaruhi keberadaan jentik/larva Aedes aegypti. ${ }^{(22)}$

Tidak adanya hubungan yang bermakna secara statistik antara kelembaban dengan keberadaan jumlah nyamuk Aedes aegypti karena di Kota Bandung tingkat suhu yang tinggi yaitu $30.5^{\circ} \mathrm{C}$ dan kelembaban yang rendah 55.75. Pada kelembaban rendah jumlah nyamuk Aedes aegypti yang ditemukan relatif sedikit, sedangkan pada kelembaban tinggi jumlah nyamuk Aedes aegypti yang ditemukan relatif banyak. Sesuai dengan penelitian di Taiwan oleh Pei Chih Wu at all, bahwa kelembaban yang rendah dan suhu yang tinggi dapat meningkatkan ketahanan hidup vektor Aedes aegypti. ${ }^{(23)}$ Kelembaban rendah dapat memperpendek usia nyamuk. Sebaliknya kelembaban tinggi nyamuk Aedes aegypti cenderung dapat bertahan hidup dalam waktu yang lebih lama. Pada kelembaban kurang dari $60 \%$ umur nyamuk akan pendek karena tidak cukup untuk siklus pertumbuhan parasit di dalam nyamuk. ${ }^{(24)}$

Suhu merupakan salah satu faktor lingkungan yang mempengaruhi perkembangbiakan jentik nyamuk Aedes aegypti. Rata-rata suhu optimum untuk perkembangbiakan vektor berkisar antara $\left(25-27^{\circ} \mathrm{C}\right)$, dan memerlukan ratarata 12 hari. Pada suhu diatas suhu optimum $\left(32-35^{\circ} \mathrm{C}\right)$ siklus hidup nyamuk untuk Aedes aegypti menjadi lebih pendek rata-rata 7 hari.

Pada suhu ekstrem yaitu $10^{\circ} \mathrm{C}$ atau lebih dari $40^{\circ} \mathrm{C}$ pertumbuhan nyamuk menjadi terhenti (mati). Toleransi terhadap suhu tergantung spesies nyamuk. Suhu yang baik bagi perkembangan jentik Aedes aegypti (25$\left.27^{\circ} \mathrm{C}\right) .{ }^{(25)}$ Berdasarkan hasil pengukuran suhu udara di lingkungan rumah responden di Kota Bandung diketahui rerata suhu $31,25^{\circ} \mathrm{C}$ dan median $30,85^{\circ} \mathrm{C}$. Berdasarkan hasil penelitian suhu udara menyebabkan pertumbuhan 
nyamuk relatif rendah. ${ }^{(22,24)}$ Suhu juga dapat mempengaruhi kelembaban, apabila suhu tinggi maka akan menyebabkan kelembaban yang rendah yang dapat menjadi faktor pendukung perkembangbiakan nyamuk. ${ }^{(24)}$

Atap rumah yang terbuat dari semen yang kedap air dan talang yang tersumbat dapat berpotensi sebagai tempat siklus hidup nyamuk Aedes aegypti, dalam penelitian ini atap menjadi tidak bermakna secara statistik dikarenakan ditemukannya atap miring $\mathrm{n}=109(68,1 \%)$. Atap yang miring tidak akan menimbulkan genangan air. Penelitian Rinawan FR dkk menjelaskan bahwa atap yang datar lebih besar meningkatkan penyakit penyakit Dengue.(26) Atap yang mengandung air ditemukan positif jentik Aedes aegypti di Cairns Australia 92,3\%. Selokan atap adalah sumber air yang jarang ditemukan namun produktif bagi Aedes aegypti berkembang biak di musim hujan. ${ }^{(27)}$

Meskipun atap rumah tidak berhubungan dengan keberadaan nyamuk Aedes aegyptidi Kota Bandung akan tetapi masyarakat harus waspada terhadap penyakit penyakit dengue, dengan diketahuinya pola penyakit dengue diharapkan pemerintah dan masyarakat dapat memprioritaskan dan menargetkan intervensi lingkungan.
Salah satunya dengan melakukan perawatan dan pembersihan talang dana atap guna menekan timbulnya penyakit dengue tersebut. ${ }^{(27)}$

\section{Kesimpulan}

Terdapat korelasi positif dan signifikan antara tempat penampungan air positif jentik dengan jumlah nyamuk Aedes aegypti. Analisis dengan Model Zero Inflated Poisson tepat digunakan pada penelitian ekologi dimana observasi dengan nilai nol lebih banyak ditemukan.

\section{Ucapan Terima Kasih}

Peneliti mengucapkan terima kasih kepada institusi Dinas Kesehatan Kota Bandung dan 10 Puskesmas di Kota Bandung yaitu UPT. Puskesmas Puter, UPT. Puskesmas Garuda, UPT. Puskesmas Ujungberung Indah, UPT. Puskesmas Sukajadi, UPT. Puskesmas Kopo, UPT. Puskesmas Ibrahim Adji, UPT. Puskesmas Arcamanik, Puskesmas Mohammad Ramdan, UPT. Puskesmas Salam, dan Puskesmas Antapani serta semua pihak yang berkonstribusi dalam proses pengumpulan data.

\section{Daftar Pustaka}

1. Bhatt S, Gething PW, Brady OJ, Messina JP, Farlow AW, Moyes CL, 
et al. The global distribution and burden of dengue. Nature. 2013;

2. Brady OJ, Gething PW, Bhatt S, Messina JP, Brownstein JS, Hoen $A G$, et al. Refining the Global Spatial Limits of Dengue Virus Transmission by Evidence-Based Consensus. PLoS Negl Trop Dis. 2012;

3. Kementerian Kesehatan RI. Profil kesehatan Indonesia Tahun 2015 [Internet]. Jakarta; 2016 [cited 2018 Oct 9]. Available from: http://www.depkes.go.id/resources/d ownload/pusdatin/profil-kesehatanindonesia/profil-kesehatanIndonesia-2015.pdf

4. Tulchinsky TH, Varavikova EA. The New Public Health [Internet]. 2009. Available from: http//www. elsevierdirect.com/companions/9780 123708908

5. Gubler DJ, Clark GG. Dengue/dengue hemorrhagic fever: the emergence of a global health problem. Emerg Infect Dis. 1995;

6. Roose A. Hubungan Sosiodemografi dan Lingkungan Dengan Kejadian Penyakit Demam Berdarah Dengue (DBD) Di Kecamatan Bukit Raya Kota Pekanbaru Tahun 2008. Universitas Sumatera Utara; 2008.
7. Wirayoga MA. Hubungan Kejadian Demam Berdarah Dengue Dengan Iklim di Kota Semarang Tahun 20062011 [Internet]. Universitas Negeri Semarang; 2013. Available from: http://lib.unnes.ac.id/19377/1/645040 7074.pdf

8. Arifin A, Ibrahim E, Ane R La. Hubungan Faktor Lingkungan Fisik dengan Keberadaan Larva Aedes aegypti di Wilayah Endemis DBD di Kelurahan Kassi-Kassi Kota Makasar 2013. 2014;1-8. Available from: http://repository.unhas.ac.id/handle/1 23456789/5544

9. Sucipto CD. Vektor Penyakit Tropis Lingkungan. Yogyakarta: Gosyen Publishing; 2011.

10. Aji R. Environmental factors and indices related to dengue vector larva in Rejang Lebong District. Int Res J Public Environ Heal. 2016;

11. Farreny $\mathrm{R}$, Morales-Pinzón $\mathrm{T}$, Guisasola $\mathrm{A}$, Tayà $\mathrm{C}$, Rieradevall $\mathrm{J}$, Gabarrell X. Roof selection for rainwater harvesting: Quantity and quality assessments in Spain. Water Res. 2011;

12. Dinkes Provinsi Jawa Barat. Profil Dinas Kesehatan Provinsi Jawa Barat 2014. Bandung; 2015. 
13. BPS Kota Bandung. Profil Kependudukan Kota Bandung [Internet]. 2016 [cited 2018 May 4]. Available from: https://bandungkota. bps.go.id/website/pdf.../KotaBandung-Dalam-Angka-2015.pdf

14. Famoye F, Singh KP. Zero-inflated Generalized Poisson regression model with an application to domestic violence data. J Data Sci. 2006;

15. Barrera R, Amador M, Clark GG. Ecological Factors Influencing Aedes aegypti (Diptera: Culicidae) Productivity in Artificial Containers in Salinas, Puerto Rico. J Med Entomol. 2006;

16. Oo TT, Storch V, Madon MB, Becker $\mathrm{N}$. Factors influencing the seasonal abundance of Aedes (Stegomyia) aegypti and the control strategy of dengue and dengue haemorrhagic fever in Thanlyin township, Yangon City, Myanmar. Trop Biomed. 2011;

17. Jacob A, Pijoh VD, Wahongan GJP. Ketahanan Hidup Dan Pertumbuhan Nyamuk Aedes Spp Pada Berbagai Jenis Air Perindukan. J e-Biomedik [Internet]. 2014 [cited 2018 Oct 22];2(3). Available from: https://ejournal.unsrat.ac.id/index.ph p/ebiomedik/article/view/6039
18. Muslim A. Faktor lingkungan yang berpengaruh terhadap kejadian infeksi virus dengue (studi kasus di kota Semarang). J Kesehat Lingkung Indones. 2004;3(1):8-12.

19. Overgaard HJ, Olano VA, Jaramillo JF, Matiz MI, Sarmiento D, Stenström TA, et al. A crosssectional survey of Aedes aegypti immature abundance in urban and rural household containers in central Colombia. Parasites and Vectors. 2017;

20. Lozano-Fuentes S, Hayden $\mathrm{MH}$, Welsh-Rodriguez C, Ochoa-Martinez C, Tapia-Santos B, Kobylinski KC, et al. The dengue virus mosquito vector Aedes aegypti at high elevation in México. Am J Trop Med Hyg. 2012;

21. Walker KR, Joy TK, Ellers-Kirk C, Ramberg FB. Human and Environmental Factors Affecting Aedes aegypti Distribution in an Arid Urban Environment. J Am Mosq Control Assoc. 2011;

22. Nakhapakorn K, Tripathi NK. An information value based analysis of physical and climatic factors affecting dengue fever and dengue haemorrhagic fever incidence. Int $\mathrm{J}$ Health Geogr. 2005; 
23. Wu PC, Guo HR, Lung SC, Lin CY, Su HJ. Weather as an effective predictor for occurrence of dengue fever in Taiwan. Acta Trop. 2007;

24. Dinata A, Dhewantara PW. Karakteristik Lingkungan Fisik , Biologi, dan Sosial di Daerah Endemis Dbd Kota Banjar Tahun 2011. J Ekol Kesehat. 2012;

25. Kementerian Kesehatan RI. Modul Pengendalian Demam Berdarah Dengue. Jakarta: Kementrian Kesehatan RI; 2011.

26. Rinawan F, Tateishi R, Raksanagara A, Agustian D, Alsaaideh B, Natalia $Y$, et al. Pitch and Flat Roof Factors' Association with Spatiotemporal Patterns of Dengue Disease Analysed Using Pan-Sharpened Worldview 2 Imagery. ISPRS Int J Geo-Information. 2015;

27. Montgomery BL, Ritchie SA. Roof gutters: A key container for Aedes aegypti and Ochlerotatus notoscriptus (Diptera: Culicidae) in Australia. Am J Trop Med Hyg. 2002; 